\title{
Competition between benthic cyanobacteria and diatoms as influenced by different grain sizes and temperatures
}

\author{
Frank Watermann ${ }^{1, *}$, Helmut Hillebrand ${ }^{2}$, Gisela Gerdes ${ }^{1}$, Wolfgang E. Krumbein ${ }^{3}$, \\ Ulrich Sommer ${ }^{2}$ \\ ${ }^{1}$ Institute for Chemistry and Biology of the Marine Environment, Marine Station, Schleusenstr. 1. \\ 26382 Wilhelmshaven, Germany \\ ${ }^{2}$ Institut für Meereskunde, Abteilung Meeresbotanik, Düsternbrooker Weg 20, 24105 Kiel, Germany \\ ${ }^{3}$ Geomicrobiology, Institute for Chemistry and Biology of the Marine Environment (ICBM), Carl von Ossietzky University, \\ Box 2503, 26111 Oldenburg, Germany
}

\begin{abstract}
An experimental laboratory set-up was used to study the influence of different grain size compositions and temperatures on the growth of benthic cyanobacteria and diatoms, and on the competition between these 2 groups. Monospecific cultures of 3 species of cyanobacteria (Merismopedia punctata, Microcoleus chthonoplastes, Oscillatoria limosa), and of 2 species of benthic diatoms (Phaeodactylum tricornutum and Nitzschia sp.) were used. The organisms were cultured in $100 \mathrm{ml}$ flasks filled with medium and 3 different kinds of sediment: (1) Sand (fine sand, 63 to $200 \mu \mathrm{m}$ ), (2) Mud-I (mixed fine sand and mud $<63 \mu \mathrm{m}$ in the ratio 80:20 wt \%), (3) Mud-II (mixed fine sand and mud in the ratio 50:50 wt \%). Experimental temperatures were 10,15 and $25^{\circ} \mathrm{C}$. At $10^{\circ} \mathrm{C}$ and $15^{\circ} \mathrm{C}$, both diatom species achieved the highest biomass on the sediments of the finest grain size $(50 \mathrm{wt} \%<63 \mu \mathrm{m})$ while cyanobacteria achieved low biomass levels. Coarsening of sediments at the same temperature levels revealed a gradually lower biomass of the diatoms. Particularly on sand, the diatoms never reached the same concentrations of chlorophyll $a$ as on mud. The cyanobacteria, on the other hand, had the highest biomass on sand at $15^{\circ} \mathrm{C}$. In the competition experiments the benthic diatom species Nitzschia sp. dominated all types of sediments at $10^{\circ} \mathrm{C}$ and $15^{\circ} \mathrm{C}$. The experiments at $25^{\circ} \mathrm{C}$ were dominated by the filamentous cyanobacterium $M$. chthonoplastes. This indicates the importance of abiotic conditions for the distribution and abundance of benthic phototrophic micro-organisms.
\end{abstract}

KEY WORDS: Competition - Cyanobacteria - Diatoms · Temperature · Sand · Mud

\section{INTRODUCTION}

Coastal shallow areas are among the most productive ecosystems in the world. Main primary producers in these systems are both planktonic and benthic cyanobacteria and diatoms. There is growing interest concerning the response of phototrophic communities to the increasing eutrophication in coastal areas. This has promoted an increasing knowledge of the ecology of phytoplankton organisms (Sommer 1994) and their benthic analogs (Krumbein et al. 1994). However,

•E-mail: frank.watermann@icbm.terramare.de there is still a shortage of information about the ecology of microphytobenthic communities. One reason may be that there are still problems with the handling of benthic micro-organisms in batch and chemostat cultures. However, some publications suggested new culture designs (Fairchild \& Lowe 1984, Pringle \& Bowers 1984, Krumbein et al. 1991, Sundbäck \& Snoeijs 1991).

Several authors stress the importance of nutrient limitation controlling the presence or absence of phytoplankton organisms (Tilman 1977, Sommer 1994). Similarly, it may be of interest to understand the factors controlling the composition and productivity of micro- 
benthic primary producers. Admiraal (1977) and Colijn $\&$ van Buurt (1975) reported that benthic diatoms are the most important components of mud flats of the Ems-Dollart estuary. Studying mud flats of the Dutch Wadden Sea, Admiraal (1977) and Admiraal et al. (1982) found that nutrients $(\mathrm{P}, \mathrm{N}, \mathrm{Si})$ were not growthrate limiting. These authors assumed that there was no direct relationship between the nutrient concentration and the distribution of benthic diatoms. MeyerReil (1994) considered the high allochthonous and autochthonous input of organic matter into the Wadden Sea and reached similar conclusions. However, the existence of nutrient limitation had so far only been shown experimentally for microalgae inhabiting sediments (Sundbäck \& Snoeijs 1991, Nilsson 1995) or growing on hard substrates (Hillebrand \& Sommer 1997). Till recently, mud flats have been the main study sites of benthic diatoms. It seems important to extend research to sandy deposits, which generally are more nutrient depleted than mud flats (Krumbein et al. 1994). On intertidal nutrient-poor sandflats, phototrophic micro-organisms with the ability for aerobic nitrogen fixation are most favoured. Cyanobacteria were found to be resistant to nutrient stress (Villbrandt et al. 1990, Villbrandt 1992) Schulz (1937) and Hoffmann (1942) described the occurrence of cyanobacteria in high-level sandy tidal flats. The term 'Farbstreifen-Sandwatt' derives from these studies. Gerdes et al. $(1985,1987)$ and Krumbein (1987) conducted various studies on the 'Farbstreifen-Sandwatt' biotopes. Cyanobacteria, on the other hand, may also occur on mud flats, although information is scarce. Colijn \& van Buurt (1975) mentioned in a subordinate remark 'only during the summer months do blue-greens occasionally occur'. Thus, little is still known about factors that may control the distribution and ecological response of both groups of microbenthic phototrophic microorganisms, cyanobacteria and diatoms, in the depositional environments of the Wadden Sea area.

This paper presents results of studies on the growth and competition of benthic cyanobacteria and diatoms using different sedimentary grain sizes at different temperatures. The aim of the studies was to contribute to a better understanding of factors controlling the distribution of benthic phototrophic micro-organisms. A further purpose was to test the hypothesis that diatoms preferentially colonize on mud-sized, and cyanobacteria on sand-sized, sediments

\section{MATERIAL AND METHODS}

Test organism. Benthic cyanobacteria: The following species were used for experimental treatment: Merismopedia punctata (Strain 86), Microcoleus chtho- noplastes (Strain 11) and Oscillatoria limosa (Strain 23). All these species occur on Mellum Island tidal flats (southern North Sea coast). M. punctata (Meyen) is a coccoid cyanobacterium that colonizes sandy tidal flats even in the lower intertidal zone. $M$. chthonoplastes (Gomont) and Oscillatoria limosa (Gomont) are filamentous species that mainly colonize the high eulittoral zones of sandy tidal flats. Both species form mats (fibrous coatings on sedimentary surfaces; Krumbein 1983). O. limosa is a pioneer organism due to its nitrogen-fixing capacity (Stal \& Krumbein 1987). Paerl et al. (1996) assume that Microcoleus sp. is a nitrogen fixer and have shown that it can produce anaerobic microsites within bundles and layers of filaments. $M$. chthonoplastes does not have heterocysts, but some authors indicate that this species is able to fix nitrogen under anoxic conditions (Krumbein \& Stal 1991). The cyanobacteria used for this study were isolated by the working group of W. E. Krumbein, University of Oldenburg. All 3 species grew in liquid cultures in the medium ASN III (Rippka et al. 1979, Stal \& Krumbein 1985 , Palinska et al. 1996).

Benthic diatoms: The species Nitzschia sp. and Phaeodactylum tricornutum were used for the experiments. Nitzschiaceae are very characteristic diatoms of the Wadden Sea. Specimens of Nitzschia sp. were isolated from a mud flat near Dangast, Jade Bay (southern North Sea coast) by the working group of W. E. Krumbein. The agar plating technique was used (Medium 5 , Schlösser 1994) to obtain monospecific cultures. $P$. tricornutum was supplied by the SAG-algae collection at the University of Göttingen. This species occurs in planktonic as well as in benthic communities (Round et al. 1990). All cultures used were non-axenic. All organisms were cultured in liquid medium prior to the experiments; thus no pre-adaptation to grain sizes occurred.

Culture techniques. All experiments were performed with 3 replicates in an enriched sea water medium, based on Medium 5 (Schlösser 1994). Filtered North Sea water (salinity $30 \%$ ) was supplied with the following additions: $1.98 \mathrm{mmol} \mathrm{l}^{-1} \mathrm{KNO}_{3}, 0.1 \mu \mathrm{mol} \mathrm{l^{-1 }}$ $\mathrm{K}_{2} \mathrm{HPO}_{4}$ and $0.08 \mu \mathrm{mol} \mathrm{l^{-1 }} \mathrm{MgSO}_{4} \times \mathrm{H}_{2} \mathrm{O}$. To this solution $5 \mathrm{ml}$ micronutrients (see ASN III, Rippka et al. 1979 ) and $30 \mathrm{ml}$ soil extract per litre were added. The $\mathrm{pH}$ value was 8 . It is generally agreed that cyanobacteria prefer ASN III or BG 11 (Rippka et al. 1979, Stal \& Krumbein 1985). However, to maintain comparable conditions Medium 5 was chosen for both cyanobacteria and diatoms. The successful growth of cyanobacteria on Medium 5 was detected in pilot tests (Watermann 1996).

The organisms were transferred to 3 different kinds of sediment (1) Sand (63 to $200 \mu \mathrm{m}$ ), (2) Mud I (mixed fine sand and Mud $<63 \mu \mathrm{m}$ in the ratio 80:20 wt \%), 
Table 1. Properties of sediments mixed for the experiments. The 3 mixtures (Sand, Mud I and Mud II) consisted of different proportions of different size classes expressed in phi values (negative logarithm of the bound dimensions of grain size classes to the base 2). Proportional sand and mud fractions in wt \%

\begin{tabular}{|lcrrrrrrr|}
\hline & \multicolumn{3}{c}{ Classification } & \multicolumn{3}{c}{ Medium sand } & \multicolumn{3}{c}{ Fine sand } & \multicolumn{2}{c}{ Mud } \\
Phi-values & $1.0-1.5$ & $1.5-2.0$ & $2.0-2.5$ & $2.5-3.0$ & $3.0-3.5$ & $3.5-4.0$ & $4.0-4.5$ \\
\hline Sand & 0 & 11 & 22 & 61 & 6 & 0 & 0 \\
Mud I & 0 & 0 & 2 & 3 & 43 & 32 & 20 \\
Mud II & 0 & 0 & 3 & 5 & 23 & 19 & 50 \\
\hline
\end{tabular}

(1967). For each replicate, chlorophyll a was determined in triplicate. The pigments were extracted from sediment in $90 \%$ aceton and measured spectrophotometrically at wavelengths of 665 and $750 \mathrm{~nm}$ before and after acidification. The chlorophyll $a$ contents were used as an alternative to counting, with errors assumed to be high in sediment samples. In the competition experiments besides the chlorophyll a content the numbers of

and (3) Mud II (mixed fine sand and mud in the ratio 50:50 wt \%) (Table 1). The sediments were dried, sieved and autoclaved. The sand was collected in the 'Farbstreifen-Sandwatt' of Mellum and used in its natural composition. The mud was collected from a mud flat in the Jade Bay. It was sieved in order to produce single fractions. These were weighed and mixed into the mud types I and II (Table 1).

The non-axenic monospecific cultures of cyanobacteria and diatoms were cultivated in $100 \mathrm{ml}$ Erlenmeyer flasks containing a $1 \mathrm{~cm}$ layer of sediment with $40 \mathrm{ml}$ of medium added. The liquid phase above the sediment was initially $2 \mathrm{~cm}$. The monospecific cultures grew in a semi-continuous system. They were diluted every $5 \mathrm{~d}$ by suspending the cells in the medium and removing $40 \%$ of the suspension and the sediment (Admiraal et al. 1982). From one part of the removed sediment the chlorophyll a content was measured; the other part was diluted and the cell numbers were determined. After resettling, medium and substrate were replaced. All work was done under a clean bench.

The competition experiments were conducted in Erlenmeyer flasks and inoculated with 5 species. Equal volume of a well-suspended culture of each species was pipetted into the experimental flasks. Therefore the proportion of species was equal for each replicate. Sampling was done as in the monospecific cultures, leading to $40 \%$ renewal of sediment and medium every fifth day. Cell numbers were determined in the competition experiments by cells per ml. Later, cell counts were transformed to biovolume by assigning nearest geometric shapes to the cells and measurement of 20 cells or trichomes in the microscope (Hillebrand et al. 1999).

Laboratory conditions. The cultures were grown in incubators at 10,15 and $25^{\circ} \mathrm{C}$, respectively. Extra cool white fluorescent tubes (Philips TLD 18W/86) provided a quantum irradiance of $90 \mu \mathrm{E} \mathrm{m} \mathrm{m}^{-2} \mathrm{~s}^{-1}$. The experiments were performed under a light period of $16 \mathrm{~h} \mathrm{~d}^{-1}$. The monospecific cultures were grown either 20 or $25 \mathrm{~d}$, the competition experiments lasted for $30 \mathrm{~d}$.

Biomass estimates. The chlorophyll a content of the cultures was measured using the method of Lorenzen cells or trichomes were determined. Before counting cell numbers, $10 \mathrm{ml}$ of the suspension from the cultures and the diluted sediment were treated in a sonication bath for $2 \min (35 \mathrm{kHz}$ ). A defined amount dependent on the sediment type was filled in counting chambers and the cells fixed with Lugol's iodine solution. The counting was done using an inverse microscope (Utermöhl 1958). Four hundred cells were counted (Lund et al. 1958 ) to reach a $95 \%$ confidence interval of $\pm 10 \%$. Chlorophyll a contents were expressed as $\mu \mathrm{g}$ per dry weight of sediment.

Statistics. Two-factor ANOVA was conducted with the chlorophyll a values at Day 20 for all monospecific cultures (Software: Statistica 5.1), with sediment type and temperatures as factors. To assess significant impact of treatments, a Tukey-HSD test was performed for all monospecific cultures and for total biovolume of all species in the competition experiments for every significant ANOVA-factor (Software: Statistica 5.1).

\section{RESULTS}

\section{Effects of temperature and grain size on the growth of monospecific cultures}

The 3 species of benthic cyanobacteria grew very slowly at $10^{\circ} \mathrm{C}$ (Fig. $1 \mathrm{a}$ to $\mathrm{c}$ ) on all the sediment types used (Table 1). The set-up at $10^{\circ} \mathrm{C}$ revealed the lowest values of all chlorophyll a concentrations measured. The cyanobacteria showed a clear increase in chlorophyll a contents at temperatures of 15 and $25^{\circ} \mathrm{C}$ (Fig. 1a to c). The chlorophyll a content of Microcoleus chthonoplastes was less than $1 \mu \mathrm{g} \mathrm{g}^{-1}$ at the end of the experiment at $10^{\circ} \mathrm{C}$ (Fig. 1b). The sediment coarseness indicated no significant growth differences with respect to low chlorophyll a contents.

Chlorophyll a contents at $15^{\circ} \mathrm{C}$ of all tested species of cyanobacteria increased as compared to $10^{\circ} \mathrm{C}$ (Fig. 1a to c). Between the sediment types used, the growth revealed differences. Both filamentous species showed higher biomass on sand compared to mud. In a relatively short incubation time, Meris- 
1a
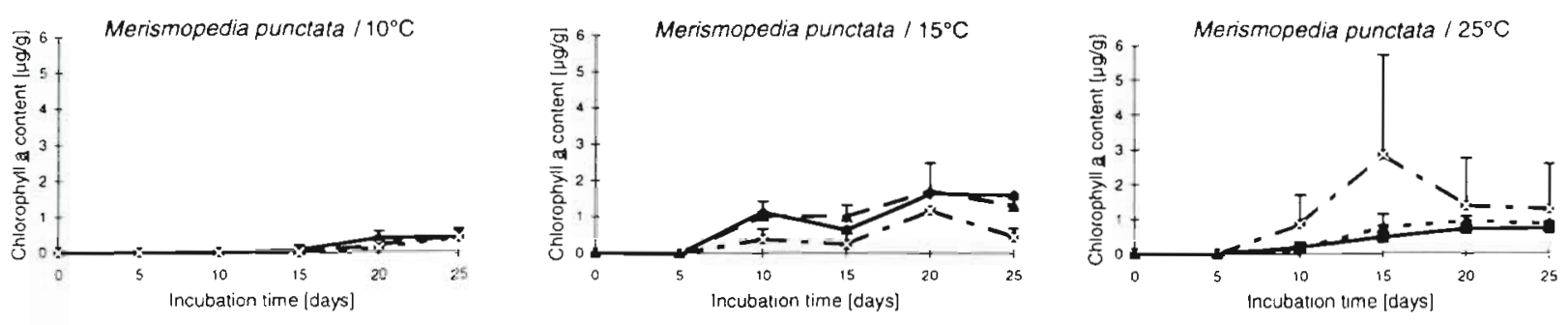

$1 b$
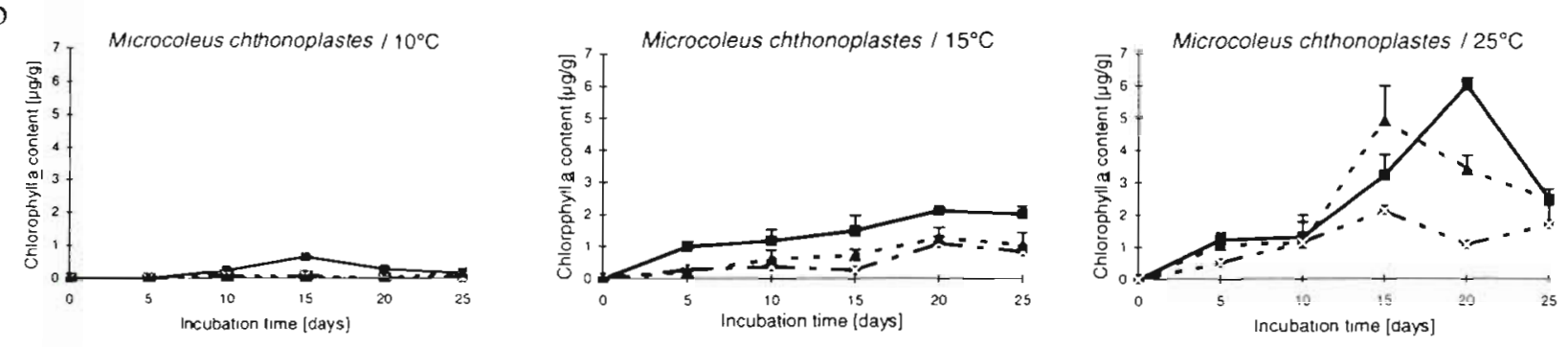

1c
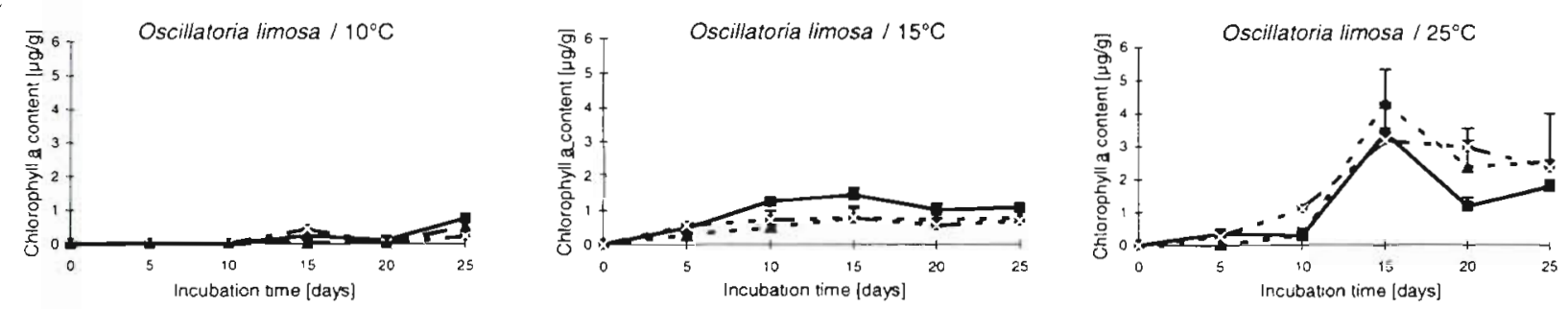

ld
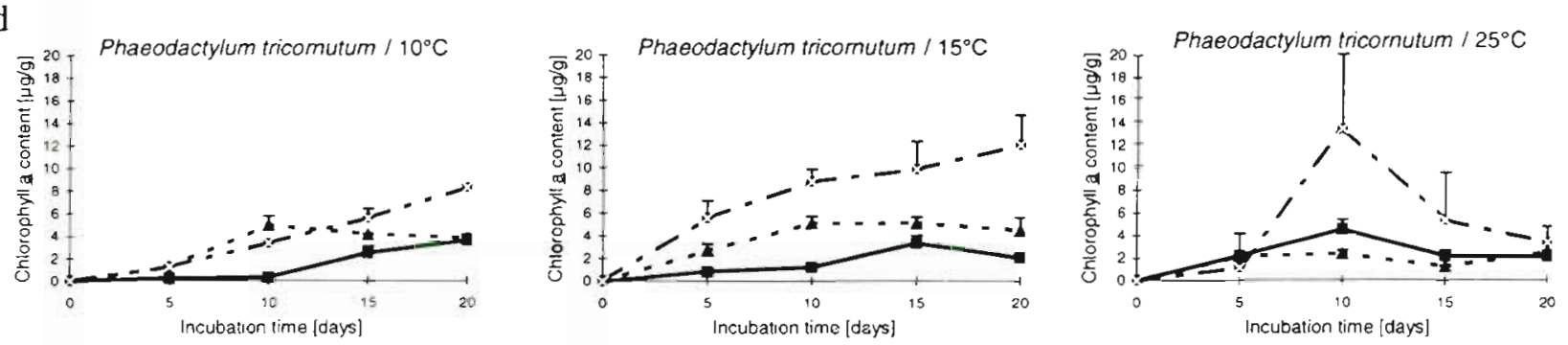

le
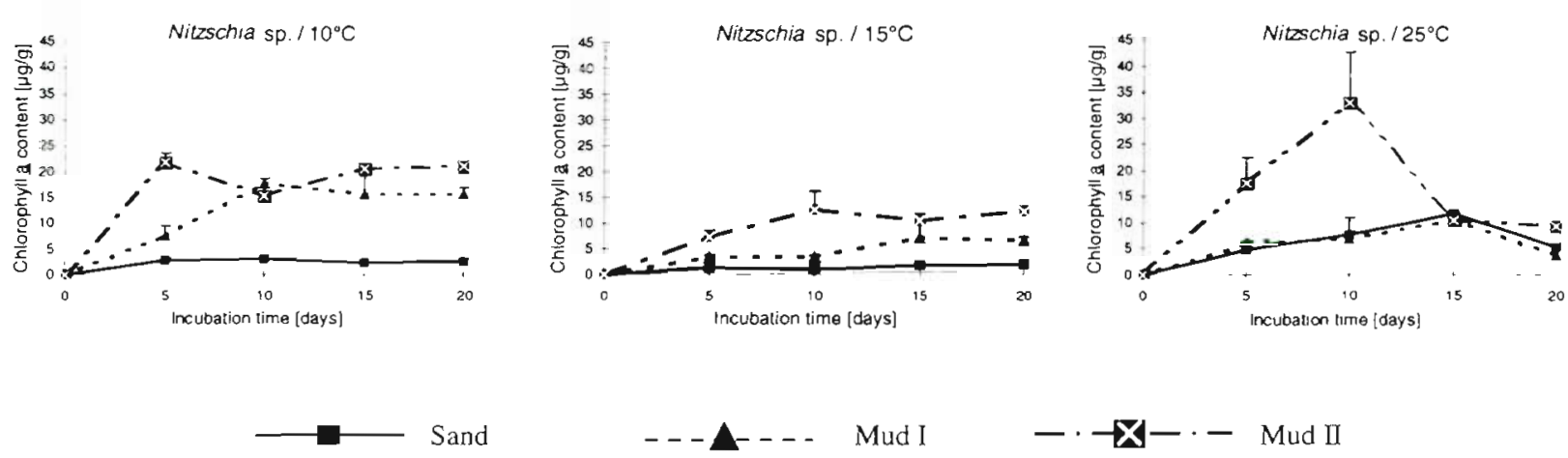

Fig. 1. The influence of different grain sizes (see Table 1) and temperatures $\left(10,15\right.$ and $\left.25^{\circ} \mathrm{C}\right)$ on growth expressed as chlorophyll a of benthic cyanobacteria and diatoms species (mean \pm SD) 
mopedia punctata and Oscillatoria limosa achieved chlorophyll a increases. This may confirm the pioneer state of O. limosa (Stal \& Krumbein 1987). M. chthonoplastes reached the highest concentration after $20 \mathrm{~d}$ (Fig. 1 a to $\mathrm{C}$ ).

At $25^{\circ} \mathrm{C}$ all 3 species achieved their highest chlorophyll a concentrations. Differences between the sediment types still existing at $15^{\circ} \mathrm{C}$ disappeared (Fig. 1a to $\mathrm{C}$ ), indicating that at $25^{\circ} \mathrm{C}$, grain size may not longer control the growth behaviour of the cyanobacteria tested; the substrate factor is apparently overruled by temperature effects.

At $10^{\circ} \mathrm{C}$ the 2 diatom species both grew fairly well on the mud types tested (Fig. 1d to e). Mainly for Nitzschia sp., the difference between growth on sand and on mud was significant (Fig. 1e). Phaeodactylum tricornutum lives under benthic as well pelagic conditions, revealed less clear differences. In general, the cultures of this species achieved a lower total chlorophyll a content, and the differences between the sediments were lower compared to Nitzschia sp. Nevertheless, for this species as well there was a clear chlorophyll a increase visible for micro-organisms inhabiting mud sediments.

The results at $15^{\circ} \mathrm{C}$ were comparable to those of the $10^{\circ} \mathrm{C}$ treatments for the 2 diatom species. All sediment types revealed differences. In all measurements at $15^{\circ} \mathrm{C}$, growth of organisms was lower if cultured on the sandy substrate (Fig. 1d to e).

At the beginning of the $25^{\circ} \mathrm{C}$ experiment, the diatom species grew well on the fraction of the finest grain size (Fig. 1d to e). But after $10 \mathrm{~d}$, the biomass decreased, although the total chlorophyll a content on Mud II was the highest relative to all values obtained. At the end of the incubation time, the content was almost the same for all treatments. Thus, a comparison of the 3 sediment types showed that the differences in the chlorophyll a concentrations almost disappeared at $25^{\circ} \mathrm{C}$.

After $20 \mathrm{~d}$, the monospecific cultures showed significantly different biomass values with respect to temperature and sediment type (2-factor ANOVA, Table 2). The cyanobacteria were generally favoured by higher temperatures (Fig. 2), especially distinct for Oscillatoria limosa and Microcoleus chthonoplastes (significant Tukey HSDtest for all 3 species, $p<0.05$ ). The coarseness of the sediment favoured $M$. chthonoplastes at every temperature, but had no significant effect on M. punctata and $O$. limosa, although for the latter the low temperature cul- ture developed better on sand than on mud (significant interaction term, Table 2). Both treatments had substantial impact on the 2 diatom species (Fig. 2) which performed better at 10 or $15^{\circ} \mathrm{C}$ than at $25^{\circ} \mathrm{C}$, and better on the Mud II sediment compared to Mud I and Sand. Significant differences were confirmed for Nitzschia sp. for all 3 sediment types and for the lowest temperature (Tukey HSD-test, $\mathrm{p}<0.05$ ), whereas 15 and $25^{\circ} \mathrm{C}$ were not significantly different. Phaeodactylum tricornutum showed significantly higher growth on Mud I compared to Sand and Mud II at $15^{\circ} \mathrm{C}$.

\section{Effects of competition on the growth of selected microbenthic primary producers (mixed cultures)}

The total chlorophyll a content of the sediments is represented in Fig. 3, and the biovolume proportions of each individual species to the total biovolume are documented in Figs. 4 to 6 . Total chlorophyll a content was significantly dependent on sediment type and temperature (Table 3). At $10^{\circ} \mathrm{C}$, the culture was dominated by Nitzschia sp. (Fig. 4). Phaeodactylum tricornutum survived in low cell numbers. All cells of the 2 species of filamentous cyanobacteria disappeared after $10 \mathrm{~d}$. Only low cell numbers of the coccoid cyanobacterium Merismopedia punctata were still alive. The total chlorophyll a content of the sediments indicates highest values for Mud II, the muddiest sediments used. This is due to the dominance of Nitzschia sp., which developed higher chlorophyll a concentrations, as can be seen in the unialgal cultures (Fig. 1e). The pattern

Table 2. Results for the experiments with unialgal cultures as analyzed with 2 -factor ANOVA with sediment type and temperature as independent factors and chlorophyll a concentration on Day 20 as the dependent variable. The table lists species name, variable and the mean squares and degrees of freedom of the measured effects. F-ratio is given with significance level (ns: not significant, $\cdots p<0.01, \cdots p<0.001)$

\begin{tabular}{|llllllr|}
\hline Species & Variable & MS effect & df & MS error & df & F-ratio \\
\hline Merismopedia & Sediment & 0.0004 & 2 & 0.115 & 18 & $0.004 \mathrm{~ns}$ \\
punctata & Temperature & 3.617 & 2 & 0.115 & 18 & $31.553 \cdots$ \\
& Interaction & 0.330 & 4 & 0.115 & 18 & $2.880 \mathrm{~ns}$ \\
Oscillatoria & Sediment & 0.384 & 2 & 0.206 & 18 & $1.868 \mathrm{~ns}$ \\
Limosa & Temperature & 10.659 & 2 & 0.206 & 18 & $51.837 \cdots$ \\
& Interaction & 1.119 & 4 & 0.206 & 18 & $5.441 \cdots$ \\
Microcoleus & Sediment & 9.580 & 2 & 0.068 & 18 & $140.45 \cdots$ \\
chthonoplastes & Temperature & 26.328 & 2 & 0.068 & 18 & $386.04 \cdots$ \\
& Interaction & 4.961 & 4 & 0.068 & 18 & $72.749 \cdots$ \\
Nitzschia sp. & Sediment & 244.529 & 2 & 1.130 & 18 & $216.46 \cdots$ \\
& Temperature & 122.233 & 2 & 1.130 & 18 & $108.20 \cdots$ \\
Phaeodactylum & Interaction & 49.570 & 4 & 1.130 & 18 & $43.881 \cdots$ \\
tricornutum & Sediment & 70.870 & 2 & 2.001 & 18 & $35.442 \cdots$ \\
& Temperature & 28.419 & 2 & 2.001 & 18 & $14.203 \cdots$ \\
& Interaction & 15.954 & 4 & 2.001 & 18 & $7.973 \cdots$ \\
\hline
\end{tabular}



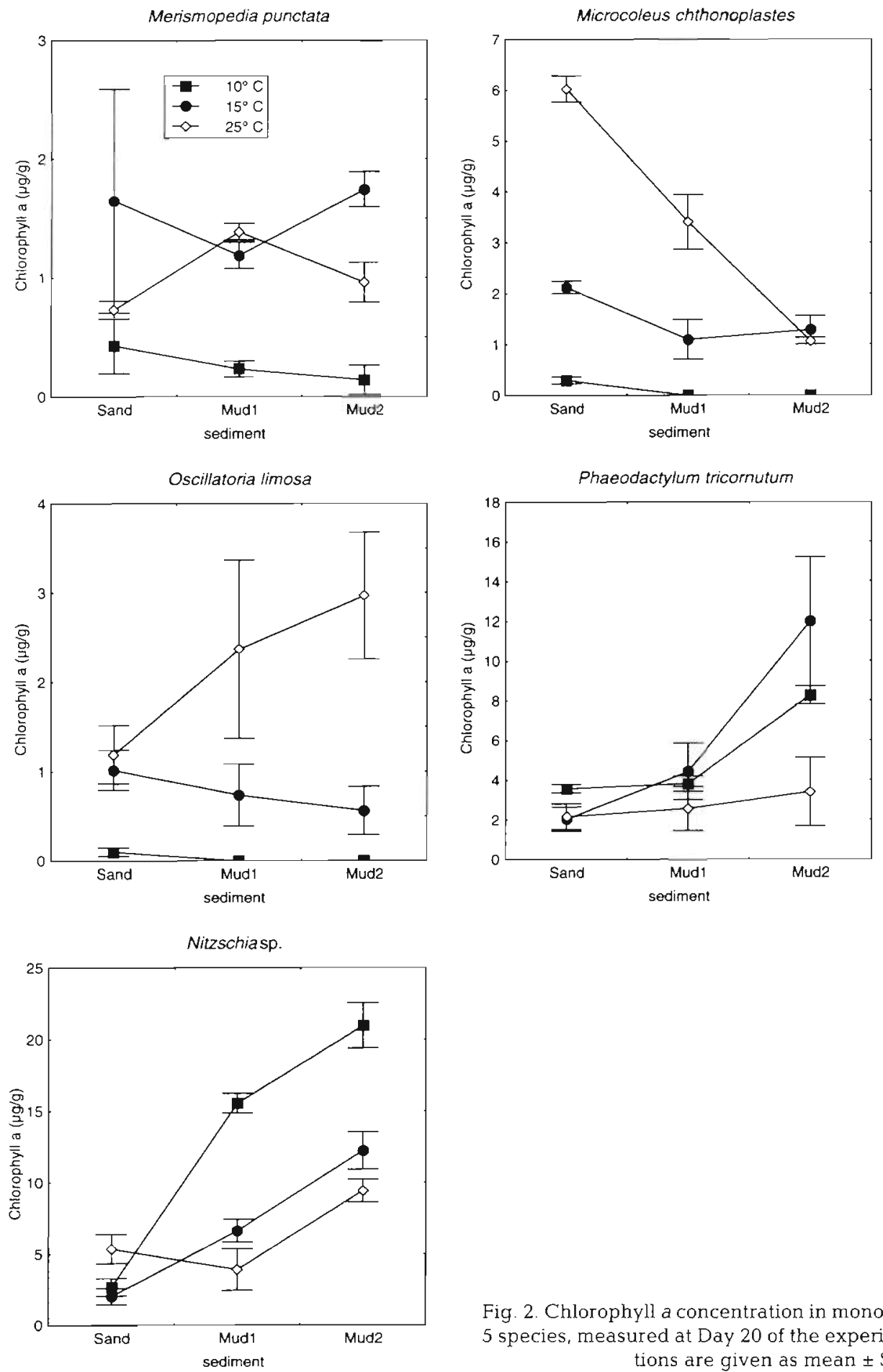

Fig. 2. Chlorophyll a concentration in monospecific cultures of 5 species, measured at Day 20 of the experiments. Concentrations are given as mean $\pm \mathrm{SE}$

of species development was similar between the unialgal cultures of both diatom species and their performance in the competition experiments at this and the other temperatures.

At $15^{\circ} \mathrm{C}$, the cultures were still dominated by Nitzschia sp. The growth rate was highest on Mud II,

and lowest on Sand (Fig. 3). Concerning the cyanobacteria, only Oscillatoria limosa was never observed following Day 5, although it was inoculated. Microcoleus chthonoplastes slightly increased on the sandy substrate at the end of the experimental time, however, at a much lower density than Nitzschia sp. (Fig. 5). 
Table 3. Results of the competition experiments as analyzed with 2-factor ANOVA on total chl a concentration on Day 20 as dependent on the factors sediment type and temperature. For details see Table 2

\begin{tabular}{|lccccc|}
\hline Variable & MS effect & df & MS error & df & F-ratio \\
\hline Sediment & 7.87 E14 & 2 & $7.68 \mathrm{E} 13$ & 18 & $10.25 \cdots$ \\
Temperature & $2.07 \mathrm{E} 15$ & 2 & $7.68 \mathrm{E} 13$ & 18 & $26.92 \cdots$ \\
Sed $\times$ temp interaction & $9.86 \mathrm{E} 14$ & 4 & $7.68 \mathrm{E} 13$ & 18 & $12.84 \cdots$ \\
\hline
\end{tabular}

At $25^{\circ} \mathrm{C}$, chlorophyll a contents were relatively low (Fig. 3) compared to the measurements at lower temperatures. The culture was dominated by the filamentous cyanobacterium Microcoleus chthonoplastes (Fig. 6). The diatom species Phaeodactylum tricornutum was not observed. Nitzschia sp. was still observed after $20 \mathrm{~d}$ on the mud fractions (Fig. 6) but disappeared after $30 \mathrm{~d}$.
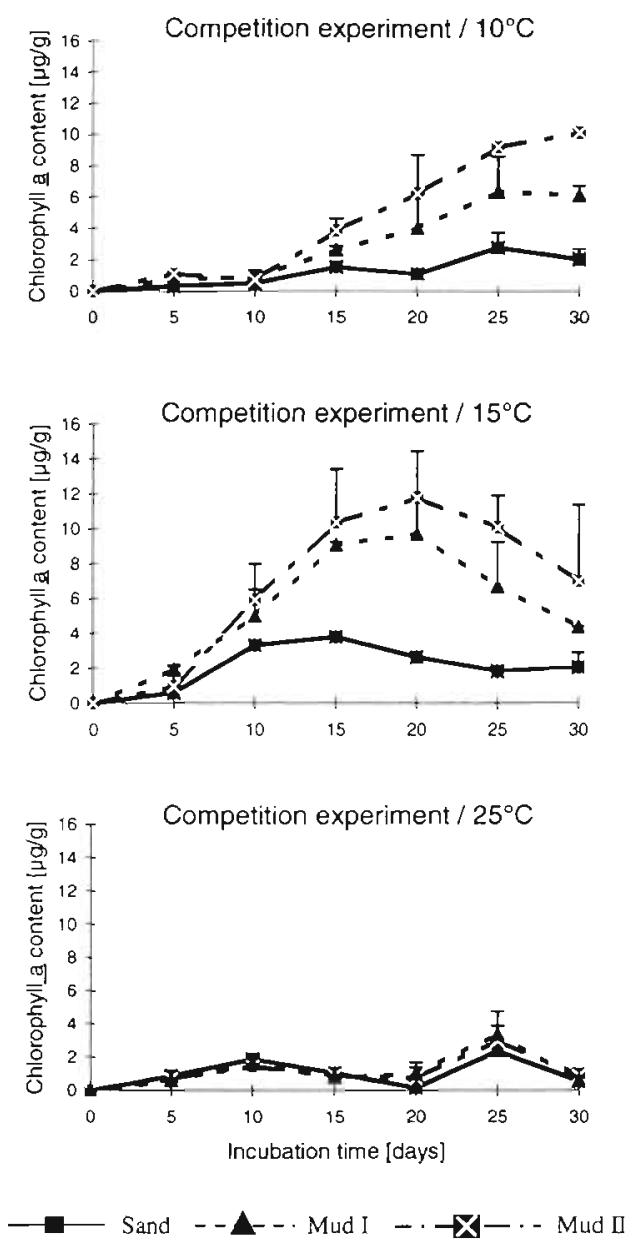

Fig. 3. Total chlorophyll a concentration (mean $\pm \mathrm{SD}$ ) of the competition experiment at 10,15 and $25^{\circ} \mathrm{C}$ for different sediment types
There was a positive correlation between the low chlorophyll a content in the competition experiment and the low content in the experiments with mono-specific cyanobacterial cultures. As a result of increased temperature, indications of substrate-specific growth disappeared (Figs. 4 to 6 ). This had already been observed for the mono-cyanobacterial cultures of Microcoleus chthonoplastes at the same temperature.

\section{DISCUSSION AND CONCLUSIONS}

One major aim of the present study was to test the hypothesis that benthic diatoms prefer muddier sediments (Colijn \& van Buurt 1975, Admiraal 1977), and cyanobacteria prefer coarser sediments for colonization (Krumbein et al. 1994). The results confirm that grain sizes play
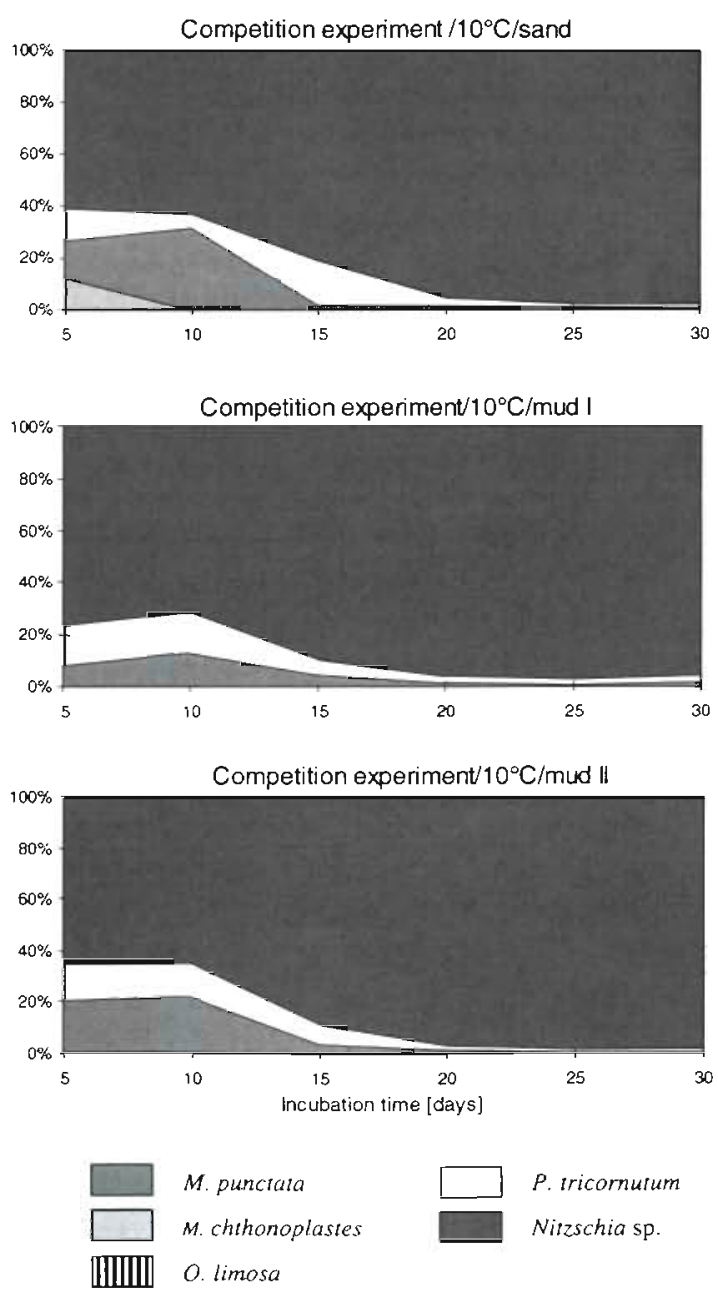

Fig. 4. Proportion of species in terms of biovolume in competition experiments at $10^{\circ} \mathrm{C}$ for different sediment types 
an important role for the distribution and abundance of microbenthic primary producers. Besides grain size temperature is also an important factor. Apparently, this is particularly important for species of the epipelon and was a very important factor determining the distribution of benthic cyanobacteria and diatoms. The importance of these abiotic conditions for sediment-inhabiting species becomes evident from the significant interaction term of ANOVA (Table 2) The growth-enhancing effect of low temperature for Nitzschia sp. becomes less obvious if the sediment type is unfavourable. On the other hand, favourable temperature conditions and favourable sediment types show synergistic effects on the growth of Microcoleus chthonoplastes. It became obvious that the chlorophyll a concentration of the sediment in the monospecific cyanobacteria cultures (Fig. 2) was less than in comparable diatom cultures. In the competition experiments as well, lower total chlorophyll a was measured
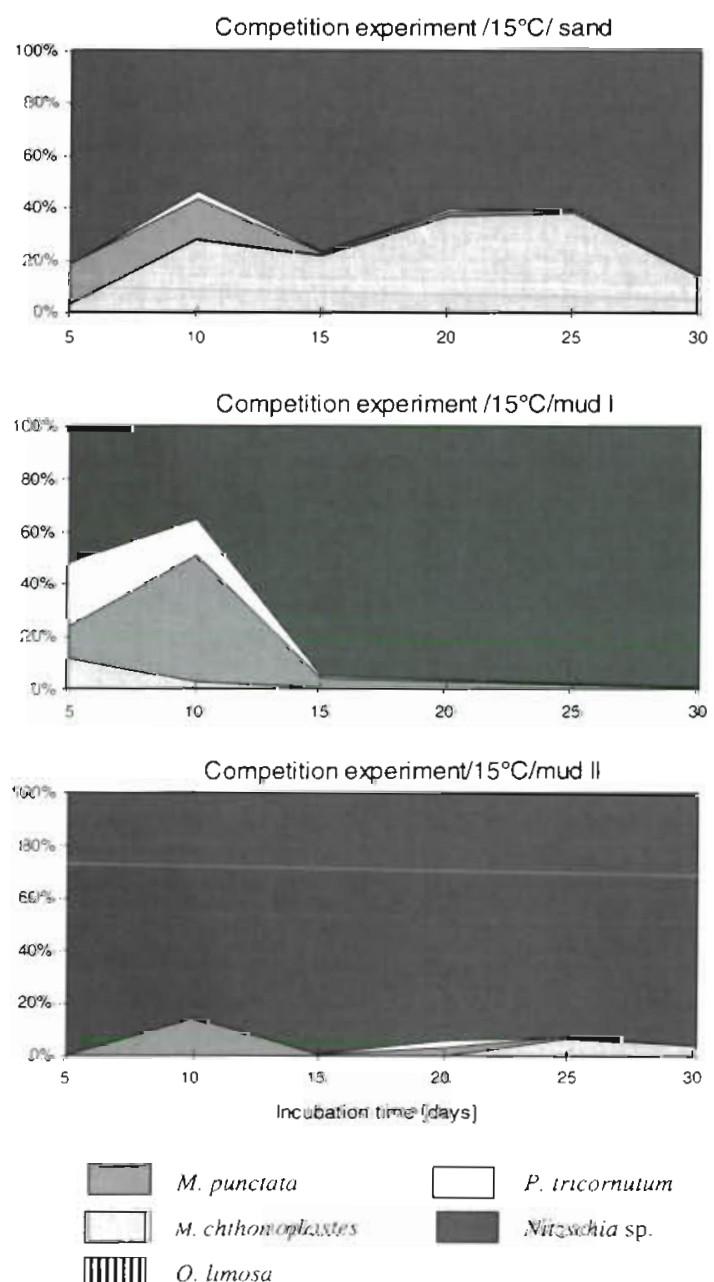

Fig. 5. Proportion of species in terms of biovolume in competition experiments at $15^{\circ} \mathrm{C}$ for different sediment types where cyanobacteria were dominant (Fig. 3)

Since the 3 cyanobacteria species did not grow well at $10^{\circ} \mathrm{C}$, even in monospecific cultures, the results of the experiments with all 5 species together may not indicate competition (negative influence). Furthermore the higher chlorophyll a content of the Nitzschia monocultures compared to the competition experiment at $10^{\circ} \mathrm{C}$ indicated the influence of factors other than competition. However, results of the experiments at 15 and $25^{\circ} \mathrm{C}$ do indicate competition between cyanobacteria and diatoms, because all species were able to grow on the 3 kinds of sediment at 15 and $25^{\circ} \mathrm{C}$ in the monospecific cultures (Fig. 1a to e). This was also confirmed by the observation that in the monospecific cultures both cyanobacteria and diatoms build visually detectable biofims. A biofilm is defined as being composed of cells and extracellular polymeric substances [EPS] immobilised at a substratum and additionally
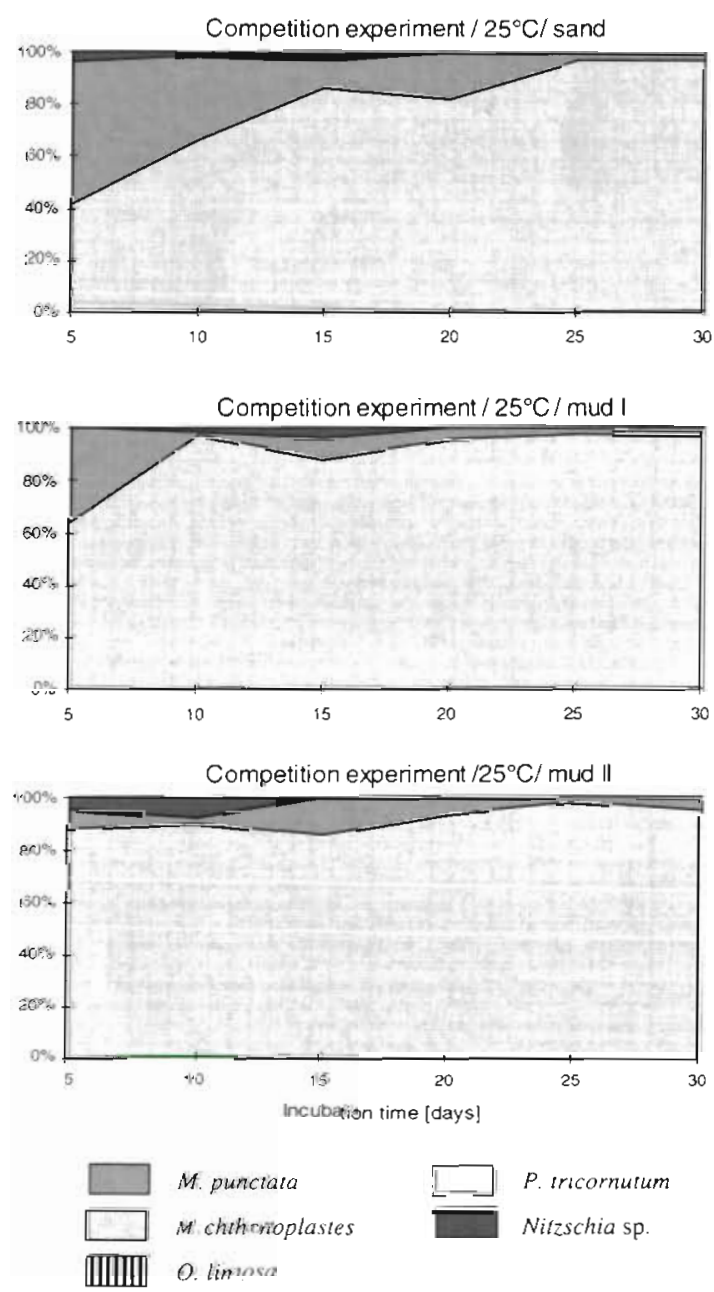

Fig. 6. Proportion of species in terms of biovolume in competition experiments at $25^{\circ} \mathrm{C}$ for different sediment types 
(Characklis \& Marshall 1990). In the competition experiment, however, Nitzschia sp. was more successful at $15^{\circ} \mathrm{C}$ ( 80 to $90 \%$ of total biovolume), whereas Microcoleus chthonoplastes dominated the biofilm at $25^{\circ} \mathrm{C}$ (97 to $98 \%$ of total biovolume).

The results of the competition experiments corresponded to the patterns seen in the monospecific cultures, with cyanobacteria favoured by high temperature and coarser sediment and diatoms dominating at low temperatures and on mud. The preference of epipelic diatoms for smaller grain size may be due to their mobile lifestyle. With larger grain size, the increased interstitial space of the sediment may be too large to support raphe-based gliding. Both cyanobacteria and diatoms have high migration rates. Round (1971) reported migration rates for 'slow' diatom species of 1.0 to $5.2 \mu \mathrm{m} \mathrm{s}^{-1}$ and for 'fast' ones of 120 to $140 \mu \mathrm{m} \mathrm{s}^{-1}$. Studying migration rates of the cyanobacterium $M$. chthonoplastes, Whale \& Walsby (1984) measured a net migration rate of $0.08 \mu \mathrm{m} \mathrm{s}^{-1}$, and Carius (1990) one of $0.04 \mu \mathrm{m} \mathrm{s}^{-1}$. The flaky texture of muddy sediments may play a decisive role for the motility of phototrophic micro-organisms. Paterson (1994) emphasized that epipelic diatoms usually are motile, while epipsammic diatoms live attached to the substratum. Filamentous cyanobacteria such as those used in this paper may be hindered by the texture and the small grain sizes of mud in both attachment and migration to the sediment surface. Cyanobacteria are photo(Häder 1987) and chemotactic organisms (Richardson \& Castenholz 1987). Geotactic responses are not known for cyanobacteria (Whale \& Walsby 1984). Diatoms show photo-, chemo- and geotaxis (Admiraal 1984).

Another factor correlated with grain sizes is light penetration into sediments. Depending on the grain size and organic content, light irradiance in sandy sediments decreases to 1 percent at a depth of 2 to $3 \mathrm{~mm}$ (Rasmussen et al. 1983). On the other hand, in fine estuarine mud the same light absorption can be observed in a considerably thinner surface layer of $0.14 \mathrm{~mm}$ (Admiraal 1984). Thus, light irradiance rapidly disappears with depth in mud. Since light is the major limiting factor for primary production, benthic photosynthesis in muddy sediments is limited to a very thin photic zone (<2 mm; Pinckney 1994). Hence, due to their high migration rates, geotaxis and high cell division rates, the diatom species studied in this paper have an advantage for occupying the muddy sediment habitats, particularly at lower temperatures.

Our experiments clearly showed the influence of grain size and temperature on microbenthic species composition. However, it should be kept in mind that the outcome of competition between these species might be influenced by other factors as well. Grain size is correlated to nutrient content of the pore water in situ, whereas in our experiments all sediments were washed and nutrients were supplied only with liquid media. Washing and autoclaving the sediment also altered other sediment properties (e.g. physicochemical gradients) which may be important in the field. Furthermore, natural sediments are influenced by water movement, which was excluded in our experiments. Finally, competitive dominance in the natural habitat is also determined by biotic interactions, e.g. herbivory

The role of temperature was also evidenced by the results of the competition studies. At $10^{\circ} \mathrm{C}$, the results were unequivocal. Growth rates of the cyanobacteria were low and those of diatoms high. Only after $10 \mathrm{~d}$ was Microcoleus chthonoplastes detected in the sand cultures while the diatoms dominated all 3 kinds of sediments. These results correspond to observations in the field (Watermann unpubl.), and may contribute to explaining the high biomass of diatoms observed in spring and autumn (Underwood \& Paterson 1993). For diatoms it seems possible that they utilize high temperatures for active photosynthesis, but require a lower temperature (at night) to complete cell division at high rates (Admiraal 1977). This condition was not given in the experiment at $25^{\circ} \mathrm{C}$ in which the temperature was constantly high.

Microcoleus chthonoplastes dominated all 3 kinds of sediments used in the $25^{\circ} \mathrm{C}$ experiments, indicating increased growth rates. Competitive dominance of cyanobacteria at higher temperatures has previously been found in phytoplankton (Tilman et al. 1986) and microphytobenthic studies (Sundbäck \& Snoeijs 1991). The dominance of $M$. chthonoplastes was independent of the substrate type at highest temperatures. In the competition experiments the temperature effects overrode the effects of the sediment type, although there was a significant interaction between both factors in monospecific cultures (Table 2). The in vitro results corresponded with field observations presented by Colijn \& van Buurt (1975), who observed a bloom of cyanobacteria on mud in summer. Normally every $12 \mathrm{~h}$ the intertidal sediments of the Wadden Sea become flooded and cooled by the tides. Especially $M$. chthonoplastes is prone to survive at high temperatures and salinity in extreme summer conditions.

Several cultures growing at high temperatures showed a decrease of total biomass at the end of the experiments. Since our cultures were not axenic, it can be assumed that under high temperatures nutrient limitation was achieved more quickly and induced bacterial degradation of biomass.

Microcoleus chthonoplastes may replace the diatoms at high temperatures by sealing of the sediment surface. The filamentous cyanobacteria $M$. chthonoplastes and Oscillatoria limosa are true microbial mat 
builders. Microbial mats are defined as fibrous coatings of sediments and rocky surfaces, which by their morphology, physiology, and arrangement in space and time interact with the physical and chemical environment to produce a laminated pattern (Krumbein 1983). The characteristic patterns of laminated biomass intertwined with siliciclastic grains is a typical phenomenon of sandy deposits, which however is usually lacking on mud. Here, the filamentous cyanobacteria only build surficial biofilms (Paterson 1994),

Due to their EPS production and motility, the diatoms also produce a biofilm that coats the mud. Such a biofilm is relatively resistant to disturbances (Madsen et al. 1993), and stabilizes the substrate (Paterson 1989 , Krumbein et al. 1994). Compared to the grain size of sand, the size of diatoms is relatively small so that diatoms usually form biofilms around single grains. This stabilizes sedimentary surfaces less effectively against erosion than the filamentous network of cyanobacteria. In the competition experiments at $15^{\circ} \mathrm{C}$, Microcoleus chthonoplastes appears on sand towards the end of the experiment. This is not surprising since the mono-specific cyanobacterial cultures of $M$. chthonoplastes at $15^{\circ} \mathrm{C}$ also show higher growth rates on sand. This suggests that $M$. chthonoplastes has an advantage on sand, probably due to its production of EPS in the form of homomers. In contrast, the diatoms produce a heteropolymer (Underwood \& Paterson 1993). The mats dominated by cells and EPS of $M$. chthonoplastes effectively stabilize the sand.

In conclusion, these experiments strengthen the importance of abiotic conditions for sediment-inhabiting phototrophic micro-organisms. On the other hand, nutrients have not been tested in these experiments. In other experiments with epilithic microflora (Hillebrand \& Sommer 1997) or with nutrient enrichment of sediments and the water column (Sundbäck \& Snoeijs 1991) it was shown that nutrient supply can control the biomass and species composition of benthic autotrophs. The dependence of the growth of phototrophic micro-organisms on grain size, temperature and nutrient content has to be tested independently, in order to be sure that results of nutrient experiments are not caused by the abiotic conditions used.

Acknowledgements. We thank Solveig Sevecke and 4 anonymous reviewers for the helpful comments on earlier drafts of this manuscript.

\section{LITERATURE CITED}

Admiraal W (1977) Influence of light and temperature on the growth rate of estuarine benthic diatoms in culture. Mar Biol 39-1-9
Admiraal W (1984) The ecology of estuarine sediment-inhabiting diatoms. Prog Phycol Res 3:269-322

Admiraal W, Peletier H, Zomer H (1982) Observations and experiments on the population dynamics of epipelic diatoms from an estuarine mud flat. Estuar Coast Shelf Sci $14: 471-487$

Carius RT (1990) Interaktionen zwischen den mattenbildenden Cyanobakterien $O$. limosa und $M$. chthonoplastes und Versuche zur Mikrobenmattengenese. Masters thesis, Universität Oldenburg

Characklis WG, Marshall KC (1990) Biofilms. In: Cohen Y, Rosenberg $E$ (eds) Microbial mats. American Society of Microbiology, Washington. John Wiley \& Sons, Chichester

Colijn F, van Buurt G (1975) Influence of light and temperature on the photosynthetic rate of marine benthic diatoms. Mar Biol 31:209-214

Fairchild GW, Lowe RL (1984) Artificial substrates which release nutrients: effects on periphyton and invertebrate succession. Hydrobiol 114:29-37

Gerdes G, Krumbein WE, Reineck HE (1985) Verbreitung und aktugeologische Bedeutung mariner mikrobieller Matten in Gezeitenbereich der Nordsee. Facies 12:75-94

Gerdes G, Krumbein WE, Reineck HE (1987) Mellum Portrait einer Insel. Verlag Waldemar Kramer, Frankfurt am Main

Häder DP (1987) Photosensory behavior in procaryotes. Microbiol Rev 51:1-21

Hillebrand H, Sommer U (1997) Response of epilithic microphytobenthos of the Western Baltic Sea to in situ experiments with nutrient enrichment. Mar Ecol Prog Ser 160: $35-46$

Hillebrand $H$, Dürselen CD, Kirschtel D, Pollingher U, Zohary $T$ (1999) Biovolume calculation for pelagic and benthic microalgae. J Phycol 35:403-424

Hoffmann C (1942) Beiträge zur Vegetation des FarbstreifenSandwattes. Kieler Meeresforsch Sonderheft 4:85-108

Krumbein WE (1983) Stromatolites - the challenge of a term in space and time. Precambrian Res 20:493-531

Krumbein WE (1987) Das Farbstreifen-Sandwatt. In: Gerdes G, Krumbein WE, Reineck HE (eds) Mellum, Portrait einer Insel. Verlag Waldemar Kramer, Frankfurt am Main, p $170-188$

Krumbein WE, Stal LJ (1991) The geophysiology of marine cyanobacterial mats and biofilms. Kieler Meeresforsch Sonderheft 8:137-145

Krumbein WE, Carius RT, Stal LJ (1991) On the interaction of the two mat-forming cyanobacteria Microcoleus chthonoplastes and Oscillatoria Limosa and laboratory experiments on bundle formation and de novo genesis of microbial mats. Kieler Meeresforsch Sonderheft 8:146-151

Krumbein WE, Paterson DM, Stal LJ (1994) Biostabilization of sediments. Bibliotheks- und Informationssystem der Carl von Ossietzky Universitat Oldenburg (BIS)

Lorenzen CJ (1967) Determination of chlorophyll and pheopigments spectro-photometric equations. Limnol Oceanogr 12:333-342

Lund JW, Kipling C, Le Cren ED (1958) The inverted microscope method of estimating algal numbers and the statistical basis of estimations by counting. Hydrobiol 11:143-170

Madsen KN, Nilsson P, Sundbäck K (1993) The influence of benthic microalgae on the stability of a subtidal sediment. J Exp Mar Biol Ecol 170:159-177

Meyer-Reil LA (1994) Mikrobielle Besiedlung und Produktion. In: Meyer-Reil LA, Köster M (eds) Mikrobiologie des Meeresbodens. Gustav Fischer Verlag, Jena, p 38-81

Nilsson C (1995) Microphytobenthos communities with emphasis on algal-nutrient relations. Dissertation, University of Göteborg 
Paerl HW, Fitzpatrick M, Bebout BM (1996) Seasonal nitrogen fixation dynamics in a marine microbial mat: potential roles of cyanobacteria and microheterotrophs. Limnol Oceanogr 30:419-427

Palinska KA, Liesack W, Rhiel E, Krumbein WE (1996) Phenotype variability of identical genotypes: the need for a combined approach in cyanobacterial taxonomy demonstrated on Merismopedia-like isolates. Arch Microbiol 166:224-233

Paterson DM (1989) Short-term changes in the erodibility of intertidal cohesive sediments related to the migratory behavior of epipelic diatoms. Limnol Oceanogr 34 $223-234$

Paterson DM (1994) Spatial variability in sediment erodibility on the island of Texel. In: Krumbein WE, Paterson DM. Stal LJ (eds) Biostabilization of sediments. Bibliotheksund Informationssystem der Carl von Ossietzky Universität Oldenburg (BIS)-Verlag, p 107-120

Pinckney J (1994) Development of an irradiance-based ecophysiologial model for interdidal benthic microalgal production. In: Krumbein WE, Paterson DM, Stal LJ (eds) Biostabilization of sediments. Biblotheks- und Informationssystem der Carl von Ossietzky Universität Oldenburg (BIS)-Verlag, p 55-83

Pringle CM, Bowers JA (1984) An in situ substratum fertilization technique: diatom colonization on nutrient-enriched, sand substrata. Can J Fish Aquat Sci 41:1247-1251

Rasmussen MN, Henriksen K, Jensen A (1983) Possible causes of temporal fluctuations in primary production of the microphytobenthos in the Danish Wadden Sea. Mar Biol 73:109-114

Richardson LL, Castenholz RW (1987) Diel vertical movements of the cyanobacterium Oscillatoria terebriformis in a sulfide-rich hot spring microbial mat. Appl Environ Microbiol 53:2142-2150

Rippka R, Derulles J, Waterbury JB, Hermann M, Stanier RY (1979) Generic assignments, strain histories and properties of pure cultures of cyanobacteria. J Gen Microbiol 111:1-61

Round FE (1971) Benthic marine diatoms. Oceanogr Mar Annu Rev 9:83-139

Round FE, Crawford RM, Mann DG (1990) The diatoms. Cambridge University Press

Schlösser UG (1994) Seawater media. Bot Acta 107:176-186

Editorial responsibility: Otto Kinne (Editor)

Oldendorf/Luhe, Germany
Schulz E (1937) Das Farbstreifensandwatt und seine Fauna, ene ökologisch-biozönologische Untersuchung an der Nordsee. Kieler Meeresforsch 1:359-378

Sommer U (1994) Are marine diatoms favoured by high Si:N ratios? Mar Ecol Prog Ser 115:304-315

Stal LJ, Krumbein WE (1985) Isolation and characterization of cyanobacteria from a marine microbial mat. Bot Mar 28: $351-365$

Stal LJ, Krumbein WE (1987) Temporal separation of nitrogen fixation and photosynthesis in the filamentous, non-heterocystous cyanobacterium Oscillatoria sp. Arch Microbiol $149: 76-80$

Sundbäck K, Snoeijs P (1991) Effects of nutrient enrichment on microalgal community composition in a coastal shallow-water sediment system: an experimental study. Bot Mar 34:341-358

Tilman D (1977) Resource competition between planktonic algae: an experimental and theoretical approach. Ecology 58:338-348

Tilman D, Kiesling R, Sterner R, Kilham SS, Johnson FA (1986) Green, bluegreen and diatom algae: taxonomic differences in competitive ability for phoshporus, silicon and nitrogen. Arch Hydrobiol 106:473-485

Underwood GJC, Paterson DM (1993) Seasonal changes in diatom biomass, sediment stability and biogenic stabilization in the Severn estuary. J Mar Biol Assoc UK 73: $871-887$

Utermöhl H (1958) Zur Vervollkommnung der quantitativen Phytoplanktonmethodik. Mitt Int Ver Limnol 9:1-38

Villbrandt $M$ (1992) Interaction of nitrogen fixation and photosynthesis in marine cyanobactertial mats (Mellum, Southern North Sea). Dissertation, University of Oldenburg

Villbrandt M, Stal LJ, Krumbein WE (1990) Interactions between nitrogen fixation and oxygenic photosynthesis in a marine cyanobacterial mat. FEMS Microbiol Ecol 74: $59-72$

Watermann $F$ (1996) Competition between benthic diatoms and cyanobacteria as influenced by different grain sizes and temperatures. Master thesis, University of Oldenburg

Whale GF, Walsby AE (1984) Motility of the cyanobacterium Microcoleus chthonoplastes in mud. Br Phycol J. 19: $117-123$

Submitted: January 29, 1999; Accepted: April 29, 1999

Proofs received from author(s): September 22, 1999 